Sharif University of Technology
Scientia Iranica
SCIENTIA
I RAN I CA

\title{
Effect of ultra-fine $\mathrm{SiO}_{2}$ and metakaolin on high strength concrete in aggressive environment
}

\author{
B. Karthikeyan and G. Dhinakaran* \\ School of Civil Engineering, SASTRA University, Thanjavur-613401, India.
}

Received 14 February 2014; received in revised form 24 June 2015; accepted 2 February 2016

\section{KEYWORDS}

Ultrafine;

Half-cell potential;

Aggressive

environment;

Deterioration;

Rate of corrosion.

\begin{abstract}
The behavior of $\mathrm{SiO}_{2}$ and metakaolin in an aggressive environment, when used separately as a supplementary cementitious material, was studied for three different replacement levels: $5 \%, 10 \%$, and $15 \% . \mathrm{SiO}_{2}$ and metakaolin were used in two states, namely unground and ground (ultra-fine). Ultra-fine state was achieved by subjecting the mineral admixtures to grinding in a planetary ball mill for an optimum period of one hour. The microstructure of the unground and ground mineral admixtures was studied using Scanning Electron Microscope and X-Ray Diffraction. The compressive strength of these systems in normal and aggressive environments was tested after initial curing in water for a month, and another subsequent curing in acid or base environment for a period of three months to arrive at the rate of deterioration. The rate of corrosion in rebars was also determined using Half-cell potential method. The results obtained from the tests were compared with control concrete. Based on the results, it was understood that concrete with $10 \%$ ground $\mathrm{SiO}_{2}$ and $5 \%$ ground metakaolin provided better resistance to deterioration and corrosion. It also exhibited improved microstructure as well as filler action. Comparing the results of the two admixtures, performance of concrete with ground metakaolin was found to be better than that of ground $\mathrm{SiO}_{2}$.

(C) 2017 Sharif University of Technology. All rights reserved.
\end{abstract}

\section{Introduction}

Concrete usage in construction industries is becoming increasingly important day by day, in which dense concrete shows excellent strength and durability properties [1]. Due to this, concrete has been widely used in construction of structures exposed to various environments ranging from mild to aggressive. Based on previous literature reviews, it can be understood that corrosion and deterioration are the major problems to which structures constructed in an aggressive environment are encountered [2]. It has been recognized that reinforcement corrosion-induced damage is one of the major causes for deterioration of reinforced

*. Corresponding author. Tel.: 914362264101 E-mail addresses: bk@civil.sastra.edu (B. Karthikeyan); gd@civil.sastra.edu (G. Dhinakaran) concrete worldwide [3]. As the corrosion progresses, the volume of rust expands and induces mechanical forces to surround concrete resulting in deterioration in the form of cracking and spalling, leading to loss of bond between concrete and reinforcement [4].

To evaluate the corrosion activity of steel reinforcement, electrochemical methods are commonly used [5]. Half-cell potential, concrete resistivity, linear polarization resistance, tafel plot, electrochemical impedance, and visual inspections are some of the methods that are used to evaluate corrosion [5-8]. Not only are reinforced cement concrete structures affected by corrosion, but also plain cement concrete is affected to the worst when exposed to aggressive environment. As an actual corrosion procedure takes a long period of time, artificial environment, simulating the aggressive environmental set up, can be used for conducting laboratory research. 
High strength concrete can be made by mineral admixtures as a partial replacement for cement and with reduced water cement ratio. Use of mineral admixtures as a partial replacement for cement is not only economical, but also helps in improving the mechanical properties and durability characteristics of concrete. The mineral admixtures used in concrete are either pozzolanic or latent hydraulic [9]. Anyway, incorporating such mineral admixtures will not contribute to early-age strength development, so the initial strength development is relatively low in such concrete made with supplementary cementitious materials [1011]. But, due to the pozzolanic reactivity of admixtures with curing age, the compressive strength is improved at later age [12]. Though mineral admixtures possess little or no cementitious properties themselves, they can form compounds possessing cementitious properties by chemically reacting with calcium hydroxide generated in cement hydration process at ordinary temperatures in a finely divided form and in the presence of moisture [13]. But, though the use of mineral admixtures yields better in the long term, their short-term strength will be low. The shortterm strength can be increased by either increasing the fineness of the mineral admixtures or curing at elevated temperatures, or using chemical activators [14]. Many works were done using readily available $\mathrm{TiO}_{2}$ nano particles and $\mathrm{SiO}_{2}$ nano particles [15-17]. Effects of nano metakaolin in microstructure and mechanical properties of cement mortar were investigated. And, considerable increase in tensile and compressive strength of mortar was observed [18]. The problem was commercially available ultra-fine particles, which cost very much higher. In the present work, it is tried to develop ultra-fine particles by grinding. The cost of grinding was found to be very cheap compared to commercially available ultra-fine particles. The objective of the present work is to develop high strength concrete by increasing the fineness of the mineral admixtures that can have better resistance to deterioration and corrosion of reinforcements in aggressive environment. Results of admixed concrete were also compared with control concrete to assess the effect of mineral admixtures. Effects of unground and ground mineral admixtures in normal and aggressive environments were also studied. $\mathrm{SiO}_{2}$ and metakaolin were chosen as the mineral admixtures in unground and ground states.

\section{Materials and methods}

\subsection{Material properties}

\subsubsection{Cement}

Ordinary Portland cement of grade 53 having a specific gravity of 3.16 was used for the research. The chemical composition of the cement is presented in Table 1.
Table 1. Chemical composition of cement, silica fume, and metakaolin.

\begin{tabular}{|c|c|c|c|}
\hline \multirow{2}{*}{ Compounds } & \multicolumn{3}{|c|}{ Concentration in percentage } \\
\hline & Cement & Silica fume & Metakaolin \\
\hline $\mathrm{SiO}_{2}$ & 23.80 & 97.36 & 53.67 \\
\hline $\mathrm{MgO}$ & 0.45 & 0.79 & 0.09 \\
\hline $\mathrm{Al}_{2} \mathrm{O}_{3}$ & 0.56 & 0.53 & 43.34 \\
\hline $\mathrm{SO}_{3}$ & 2.80 & 0.51 & 0.27 \\
\hline $\mathrm{Fe}_{2} \mathrm{O}_{3}$ & 6.09 & 0.15 & 0.46 \\
\hline $\mathrm{CaO}$ & 66.30 & 0.14 & 0.37 \\
\hline $\mathrm{P}_{2} \mathrm{O}_{5}$ & - & 0.09 & 0.12 \\
\hline $\mathrm{Na}_{2} \mathrm{O}$ & - & 0.06 & 0.12 \\
\hline $\mathrm{Cl}$ & - & 0.02 & 0.02 \\
\hline $\mathrm{K}_{2} \mathrm{O}$ & - & 0.29 & 0.17 \\
\hline $\mathrm{MnO}$ & - & 0.01 & - \\
\hline $\mathrm{PbO}$ & - & 0.01 & 0.04 \\
\hline $\mathrm{CeO}_{2}$ & - & - & 0.04 \\
\hline $\mathrm{V}_{2} \mathrm{O}_{5}$ & - & - & 0.04 \\
\hline $\mathrm{ZrO}_{2}$ & - & - & 0.01 \\
\hline $\mathrm{TiO}_{2}$ & - & 0.01 & 1.19 \\
\hline $\mathrm{Cr}_{2} \mathrm{O}_{3}$ & - & 100 ppm & 0.02 \\
\hline $\mathrm{ZnO}$ & - & $70 \mathrm{ppm}$ & $60 \mathrm{ppm}$ \\
\hline $\mathrm{CuO}$ & - & $51 \mathrm{ppm}$ & $56 \mathrm{ppm}$ \\
\hline $\mathrm{Ru}$ & - & $47 \mathrm{ppm}$ & \\
\hline $\mathrm{SrO}$ & - & - & $53 \mathrm{ppm}$ \\
\hline $\mathrm{Pd}$ & - & - & $96 \mathrm{ppm}$ \\
\hline $\mathrm{NiO}$ & - & - & $95 \mathrm{ppm}$ \\
\hline
\end{tabular}

\subsubsection{Aggregate}

River sand was used as fine aggregate and the fineness modulus of the fine aggregate was 3.17 , and it belonged to coarse sand category, which can be used for concrete mixing. Aggregate, passing through $16 \mathrm{~mm}$ sieve and retained on $12.5 \mathrm{~mm}$ sieve, was used as coarse aggregate in the concrete mixture. The fineness modulus of the coarse aggregate was obtained as 7.5.

\subsubsection{Mineral admixtures}

Silica fume and metakaolin are the pozzolans used as partial substitution for cement in the present research work. Silica fume is a by-product obtained in the manufacture of silicon or ferrosilicon alloy. It is extremely fine and has an average particle size of $0.1 \mu \mathrm{m}$. The micro-silica used for the research is obtained from Oriental Exporters, Navi Mumbai, Maharashatra, India. Metakaolin is finer than cement particles, but coarser than silica fume. The average particle size of silica fume is reported as $1.5 \mu \mathrm{m}$ [9]. The metakaolin used for the research was obtained from Jeetmull Jaichandlall (M) Pvt Ltd suppliers, Chennai, India. Table 1 shows the chemical composition of the obtained micro-silica 


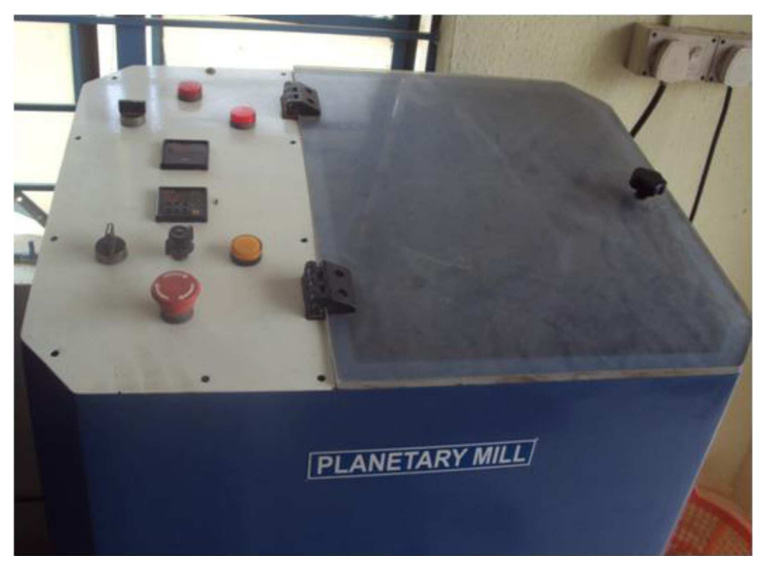

Figure 1(a). Planetary ball mill.

and metakaolin obtained from XRF. The silica fume and the metakaolin used in the form as received from the suppliers are represented as unground silica fume (UGSF) and unground metakaolin (UGMK), respectively, in the present work.

\section{Ultra-fine silica fume and metakaolin}

Ultra-fine silica fume and metakaolin were obtained by subjecting the mineral admixtures separately to different hours of grinding in a planetary ball mill using zirconium balls [19-21]. Figure 1(a) shows the planetary ball mill of $320 \mathrm{rpm}$ used for grinding silica fume. $10 \mathrm{~mm}$ zirconium balls were used in grinding process. Initially, 18 balls were added and after twenty minutes, the number of balls was increased to 26 . Initially, $100 \mathrm{~g}$ of silica fume was fed into the ball mill; the sample was ground for 1 hour. Later, $50 \mathrm{~g}$ of micro silica was ground for 1 hour to study the effect of grinding. The grinding efficiency of the mill depends upon several parameters such as the amount of materials to be ground, the ratio of the material to the grinding balls, and the size of the grinding balls. The percentage of reduction in size for different hours of grinding is listed in Table 2. It can be noted that initially, when the ball mill was loaded with its full capacity, the percentage reduction in size was only

Table 2. Size of silica fume and Metakaolin: ground and unground.

\begin{tabular}{ccccc}
\hline $\begin{array}{c}\text { Sample } \\
\text { type }\end{array}$ & $\begin{array}{c}\text { Quantity } \\
\text { used for } \\
\text { grinding } \\
(\mathbf{g})\end{array}$ & $\begin{array}{c}\text { Duration } \\
\text { of } \\
\text { grinding }\end{array}$ & Size & $\begin{array}{c}\text { Percentage } \\
\text { reduction } \\
\text { in size }\end{array}$ \\
\hline UGSF & - & - & $0.638 \mu \mathrm{m}$ & - \\
GSF & 100 & 1 hour & $0.505 \mu \mathrm{m}$ & 20.84 \\
GSF & 50 & 1 hour & $156.6 \mathrm{~nm}$ & 75.45 \\
UGMK & - & - & $1751 \mathrm{~nm}$ & - \\
GMK & 100 & 1 hour & $1738 \mathrm{~nm}$ & 0.74 \\
GMK & 50 & 1 hour & $419.9 \mathrm{~nm}$ & 75.84 \\
\hline
\end{tabular}

$20.84 \%$, later the quantity was reduced to $50 \%$, and a greater percentage of reduction in size about $75.45 \%$ from the original size of micro-silica was obtained. The same procedure was also adopted for grinding metakaolin. It can be seen that major reduction in size of about $75.84 \%$ was obtained when $50 \mathrm{~g}$ of metakaolin were subjected to grinding for 1 hour. The percentage reduction in size is listed in Table 2. As the particles reached ultra-fine size at one-hour grinding, the experiments were carried out on samples ground for one hour only, sustained as the optimum duration for obtaining finer particles. The silica fume and the metakaolin, subjected to grinding and then used for casting specimens, were represented as ultrafine Ground Silica Fume (GSF) and ultra-fine ground metakaolin (GMK), respectively, in the present work.

\subsubsection{Acids}

Sulphate attack is considered as one of the most common reasons for deterioration in concrete. It may lead to severe damages such as cracking, expansion of concrete, and disintegration of cement paste [22]. To study the effect of sulphate attack on concrete and also to know their behavior in aggressive industrial environment, the cubes were subjected to curing in $\mathrm{H}_{2} \mathrm{SO}_{4}$ acids, with which the structures are encountered frequently in industries. The acids were diluted before their use, and $1 \% \mathrm{H}_{2} \mathrm{SO}_{4}$ was used in this work to observe the deterioration of concrete when cured in it.

\subsubsection{Bases}

Corrosion in reinforced concrete is of two types: carbon-induced corrosion and chloride-induced corrosion [4]. For marine concrete structures, chloride attack is considered as one of the most severe durability problems [1]. To bring the effect of the marine environment, $5 \%$ sodium chloride was used in this study for curing the concrete specimens to study their behavior in the aggressive marine environment.

\subsubsection{Steel}

Reinforcing steel corrosion in concrete has been considered as the most severe problem in reinforced concrete structures throughout the world [23]. To study the corrosion resisting properties of reinforced concrete in the aggressive environment using a half-cell potential method, high-yield-strength cold-twisted bars of $12 \mathrm{~mm}$ diameter size have been used.

\subsubsection{Super plasticizer}

A commonly available super plasticizer CONPLAST SP 430 from FOSROC Company was used to obtain the workable concrete mix.

\subsection{Water-cement ratio}

The water cement ratio was kept between 0.31 and 0.33 as the percentage of silica fume increased; the requirement of required water also increased. 


\subsection{Concrete mixture proportions}

A high-strength concrete grade of M50 has been used in this research work. The mix design was arrived using ACI method [24]. A total of 7 combinations, each for silica-fume and metakaolin, were prepared for the present research work. CONTROL, UGSF5, UGSF10, UGSF15, GSF5, GSF10, and GSF15 are the mixes made using unground and ultra-fine ground silica fume; CONTROL, UGMK5, UGMK10, UGMK15, GMK5, GMK10, and GMK15 are the mixes made with unground and ultra-fine ground metakaolin. The combinations were made by partially replacing cement with ultra-fine and unground mineral admixtures (silica fume and metakaolin) in $5 \%, 10 \%$, and $15 \%$. The obtained mix ratio is 1:1.04:2.13 (Cement: Fine aggregate: Coarse aggregate). The mix proportion details are shown in Table 3.

\subsection{Specimen details}

Concrete cubes of size $100 \mathrm{~mm} \times 100 \mathrm{~mm} \times 100 \mathrm{~mm}$ were cast as per BS 1881 [25] for studying the compressive strength of specimens cured in the aggressive environment. The reinforced concrete specimens used for finding the corrosion rate of rebars in concrete were cylinders of size $60 \mathrm{~mm} \times 120 \mathrm{~mm}$ embedded centrally with $12 \mathrm{~mm}$ diameter steel rods, as shown in Figure 1(b). The specimens were prepared by partially replacing cement in the concrete mix in $5 \%, 10 \%$, and $15 \%$ of unground silica fume (UGSF), Ultra-Fine Ground Silica Fume (UFGSF), unground metakaolin (UGMK), and ultra-fine metakaolin (GMK). In addi-

Table 3. Mix proportioning.

\begin{tabular}{ccc}
\hline Sl. no & Parameters & Mix properties \\
\hline 1. & Grade of concrete & M 50 \\
2. & Mix Proportion & $1: 1.04: 2.13$ \\
3. & Cement $\left(\mathrm{kg} / \mathrm{m}^{3}\right)$ & $522.57 \mathrm{~kg} / \mathrm{m} 3$ \\
4. & Fine Aggregate $\left(\mathrm{kg} / \mathrm{m}^{3}\right)$ & $544.18 \mathrm{~kg} / \mathrm{m}^{3}$ \\
5. & Coarse Aggregate $\left(\mathrm{kg} / \mathrm{m}^{3}\right)$ & $1113.84 \mathrm{~kg} / \mathrm{m}^{3}$ \\
6. & Water & $182.91 / \mathrm{m}^{3}$ \\
7. & Super plasticizer & $1-3(1)$ per $100 \mathrm{~kg}$ of \\
\end{tabular}

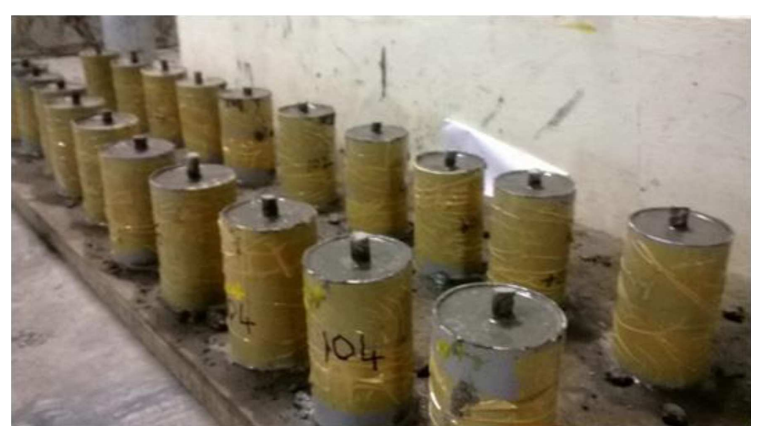

Figure 1(b). Specimen for half-cell potential testing.

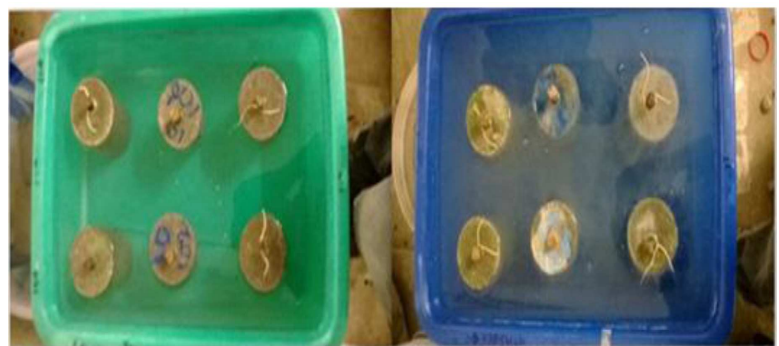

Figure 1(c). RCC cylinder specimens subjected to curing in acid and base environments.

tion, control concrete specimens were cast in which no partial replacement was done.

\subsection{Curing environment}

All the specimens were subjected to a normal curing for 28 days in water, and then the specimens were taken out and subjected to curing in acid and base environments; plain concrete was cured in the aggressive environment for a period of three months; specimens with steel reinforcement were subjected to curing for a period of 28 days only as steel gets corroded in a faster way. The solutions were changed periodically once in seven days so that the effect of acid and bases was maintained constant. Figure 1(c) shows the curing of RCC cylindrical specimens in the aggressive environment.

\subsection{Testing methods}

The strength tests were performed to study and compare the deterioration rate of specimens cured in different environments. A $3000 \mathrm{kN}$ compression testing machine was used to measure the compressive strength. The corrosion of steel reinforcements embedded in concrete specimens was monitored by Half-cell potential method using Saturated Calomel Electrode (SCE) as a standard reference electrode as per ASTM C876-91, and Table 4 shows the probability of reinforcement corrosion [26]. Half-cell potential method has been a widely accepted method for detection of reinforcement corrosion in concrete structures [27]. In this test, initially, the values obtained in half-cell potential method will be positive for the specimens which indicate that the specimen has not corroded yet, or yet to be corroded. When corrosion starts, the value will become negative. The value will be very high

Table 4. Probability corrosion range for steel reinforcement [21].

\begin{tabular}{ll}
\hline \multicolumn{2}{c}{ Open circuit potential values } \\
\hline $\mathrm{mV}$ vs SCE & Corrosion condition \\
$<-426$ & Severe condition \\
$<-276$ & High $(<90 \%$ risk of corrosion $)$ \\
-126 to -275 & Intermediate corrosion risk \\
$>-125$ & Low $(<10 \%$ risk of corrosion $)$ \\
\hline
\end{tabular}




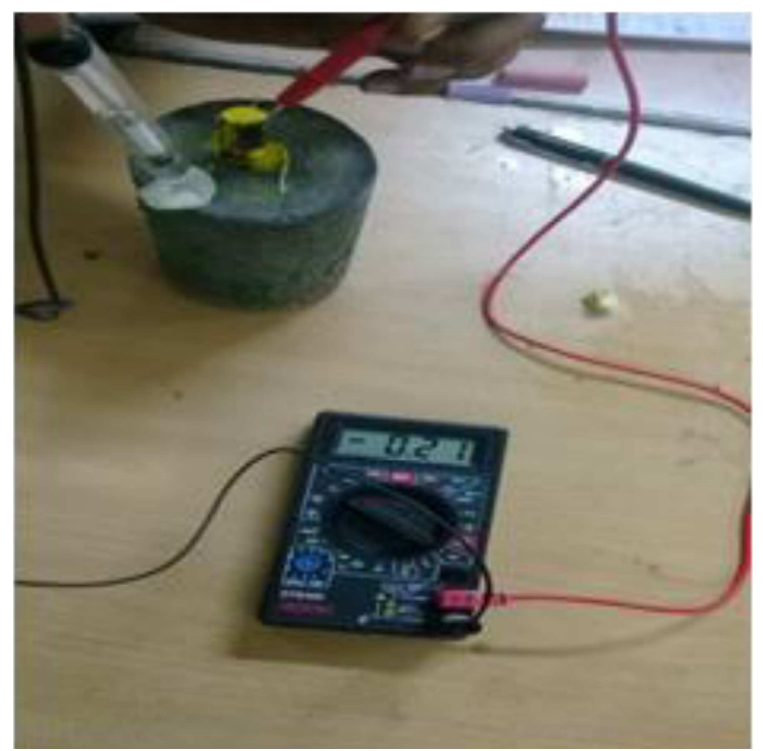

Figure 1(d). Testing for corrosion of bars using multi meter by HCP method.

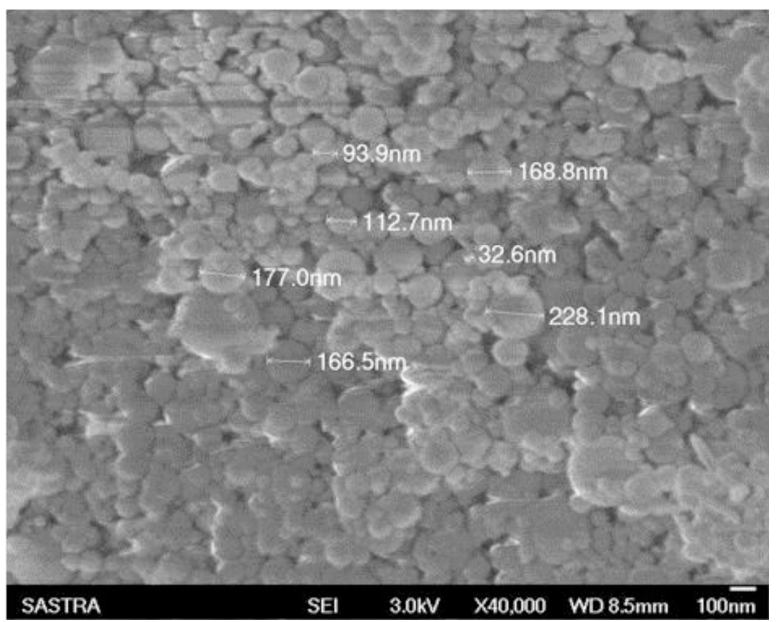

Figure 2(a). Morphology of UGSF.

initially and will slowly decrease and reach the negative value. Figure 1(d) shows the test being conducted on specimens.

\section{Results and discussion}

\subsection{Microstructure study}

Investigations regarding the effect of grinding in ultra-fine silica fume were carried out by performing microstructure study through scanning electron microscopy and X-ray diffraction. The SEM results of UGSF, GSF, UGMK, and GMK are shown from Figures 2(a) to 2(d). The results represent the arrangement of particles, shapes, and dimensions of the particles. The sizes of the ground and unground samples can also be seen. Based on the SEM images, it is understood that there is a considerable reduction in size. Also, it can be seen that the micro structure of the

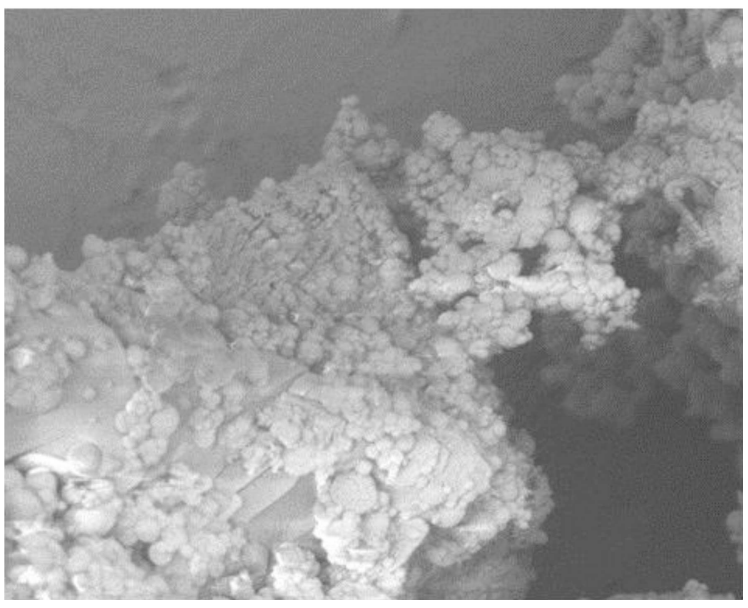

Figure 2(b). Morphology of GSF.

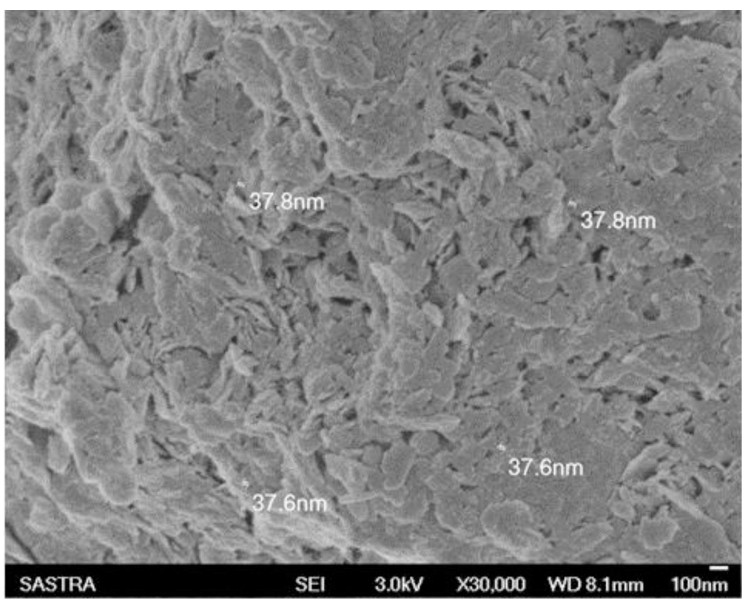

Figure 2(c). Morphology of UGMK.

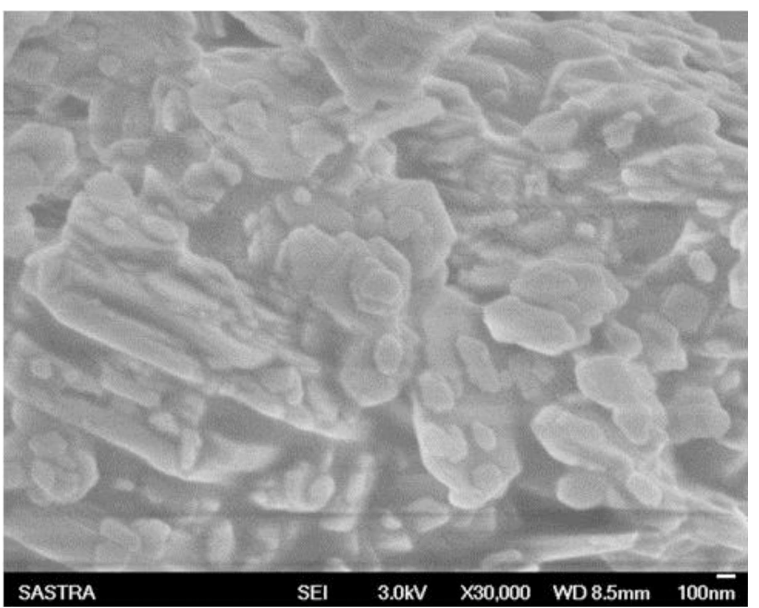

Figure 2(d). Morphology of GMK.

ground particles is not disturbed and more spherical shapes can be seen in silica fume and metakaolin ground for 1 hour. It is indicated that the grinding of particles was reduced only its size further and sphericity was not affected. As the particles achieved finer size in 1 hour grinding, the optimum duration of 
grinding is fixed as 1 hour. When it is subjected to long periods of grinding, the spherical shape of the particles may even get reduced, but in the present study, the work has been restricted to 1 hour grinding considering the economy. Also, if the grinding period was increased in order to obtain finer size, the shapes of the particles would become irregular, instead of being spherical, and proper bonding could not be ensured in such shapes. Hence, it can be taken that grinding of silica fume, or metakaolin, does not affect the microstructure of the material; further, silica ground and metakaolin ground to ultra-fine size can make the microstructure sounder, resulting in reduction of micro-cracks. XRD results, shown in Figures 3(a) to 3(d), indicate no difference in the chemical properties of UGSF and GSF and between UGMK and GMK powders, confirming that the properties of the mineral admixtures are not altered even after grinding.

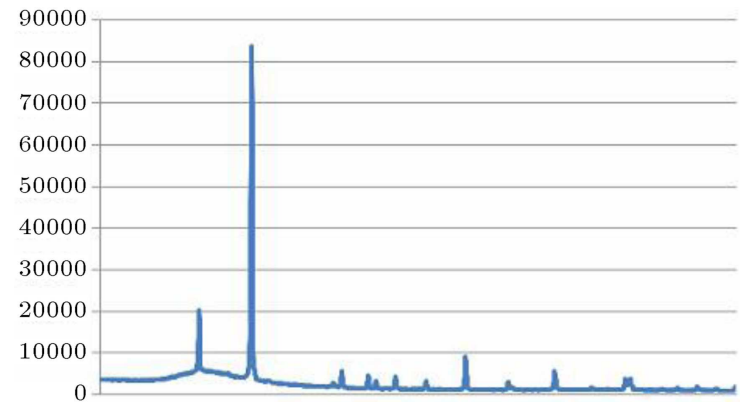

Figure 3(a). XRD pattern of UGSF.

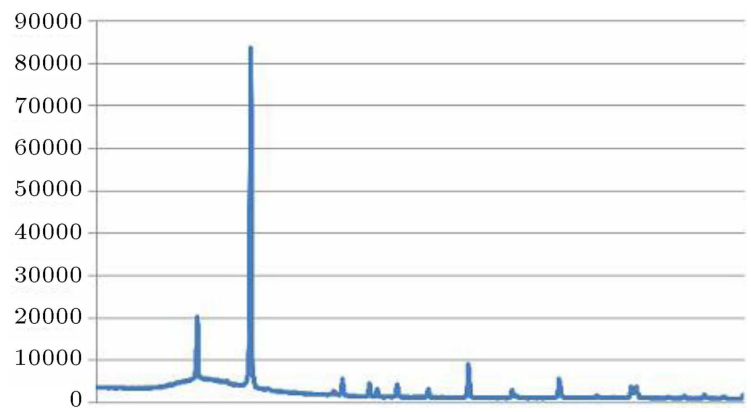

Figure 3(b). XRD pattern of GSF.

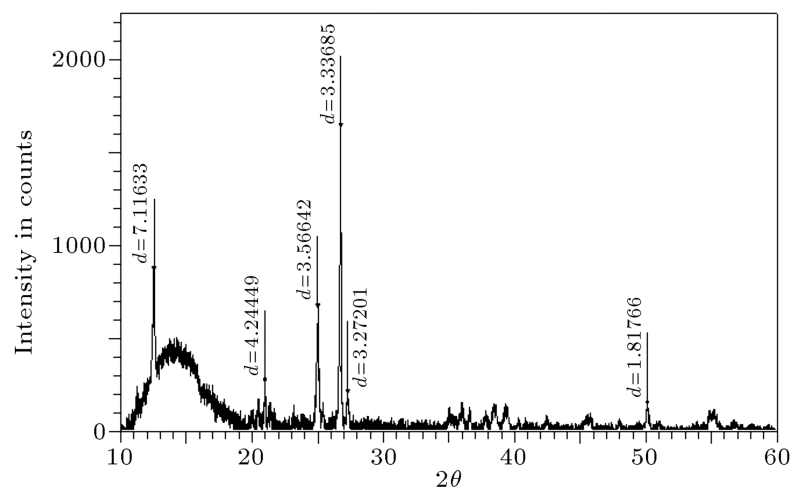

Figure 3(c). XRD pattern of UGMK.

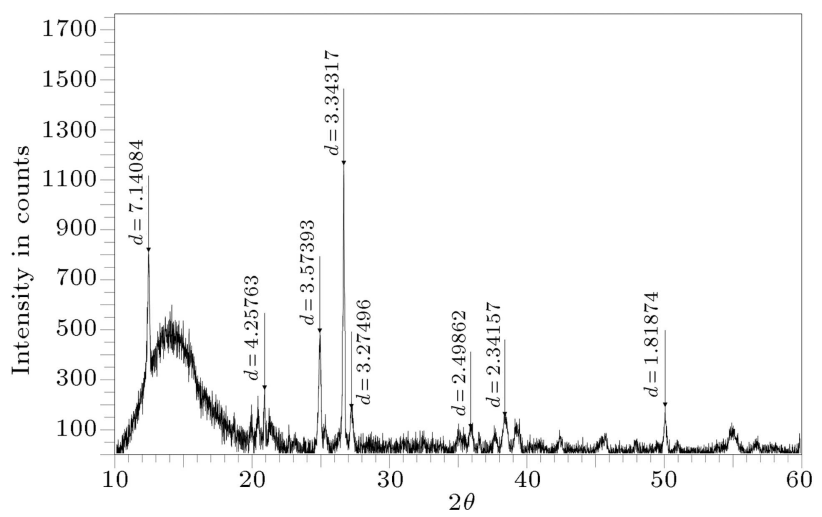

Figure 3(d). XRD pattern of GMK.

\subsection{Comparison of compressive strength and rate of deterioration}

3.2.1. Compressive strength after curing in water It is understood from the results of compressive strength of concrete specimens at the age of 28 days that a higher strength was obtained for GMK concrete with $69.26 \mathrm{MPa}$ reaching strength well beyond the target mean strength for M50 grade concrete; GSF15 registered a lower strength of 38.59 $\mathrm{MPa}$. Several factors attribute to the higher strength in UFGMK, namely low water-cement ratio, optimum partial replacement of cement by suitable supplementary cementitious materials, better pores filling effect, and pozzolanic reaction of ultra-fine metakaolin and cement particles. The lower strength results for specimens cast with UGSF and GSF may be due to higher replacement of ultra-fine particles of silica fume. The replacement level with $15 \%$ of ultra-fine is not sufficient to fill the pores present in concrete; a larger percentage of replacement is required since many of the ultra-fine particles are dissolved. So, GSF15 specimens lacked proper filling of pores in concrete and a better pozzolanic reaction, leading to reduction in strength. But, adding ultra-fine cement in an optimum content, like $10 \%$, yielded strength larger than the mean target strength of the mix, but less than the strength of concrete with metakaolin as a partial replacement. It is found that metakaolin in both states has obtained better results than silica fume. A comparison of all mixes with control concrete for 28day curing in water is shown in Figure 4(a).

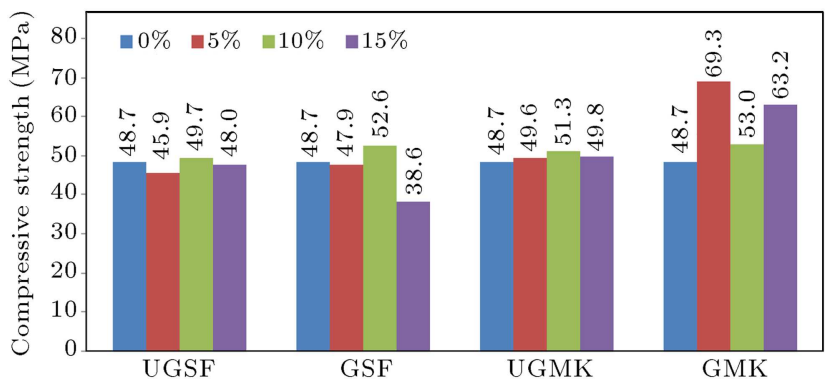

Figure 4(a). Compressive strength after curing in water. 


\subsubsection{Compressive strength after curing in aggressive environment}

On comparing the compressive strength results of specimens cured in the aggressive environment $\left(\mathrm{H}_{2} \mathrm{SO}_{4}\right.$ and $\mathrm{NaCl}_{2}$ ), it is found that among the cubes cast with unground silica fume, UGSF10 showed a higher compressive strength of $37.65 \mathrm{MPa}$ and $40.71 \mathrm{MPa}$ in $\mathrm{H}_{2} \mathrm{SO}_{4}$ medium and $\mathrm{NaCl}_{2}$ medium, respectively; GSF10 showed a higher strength of $44.93 \mathrm{MPa}$ in $\mathrm{H}_{2} \mathrm{SO}_{4}$ medium and $39.91 \mathrm{MPa}$ in $\mathrm{NaCl}_{2}$ medium, respectively, among the specimens cast using ultra-fine silica fume as the mineral admixture, whereas a much higher strength of $40.1 \mathrm{MPa}$ was shown by UGMK5 in $\mathrm{H}_{2} \mathrm{SO}_{4}$ medium; $43.47 \mathrm{MPa}$ was shown by UGMK15 in $\mathrm{NaCl}_{2}$ medium among the unground metakaolin category; GMK5 and GMK15 showed higher compressive strengths of $45.4 \mathrm{MPa}$ and $54.23 \mathrm{MPa}$ in $\mathrm{H}_{2} \mathrm{SO}_{4}$ and $\mathrm{NaCl}_{2}$ mediums, respectively, in ultra-fine metakaolin category. In general, on observing the overall results, it is clear that unground metakaolin and ultra-fine metakaolin have given higher compressive strength than unground silica fume or ultra-fine silica fume. A comparison of all mixes with control concrete for 28day curing in water is shown in Figures 4(b) and 4(c).

\subsubsection{Rate of deterioration after curing in $\mathrm{H}_{2} \mathrm{SO}_{4}$}

It is seen from the results that control concrete deteriorated more, showing $67.24 \%$ deterioration. UGSF10 and UGSF15 showed less deterioration of $14.58 \%$ and $17.01 \%$, respectively, in acid environment. The deterioration rates of other mixes are slightly higher than this, but not up to the limit of control concrete and are well below that range. So, it is understood that

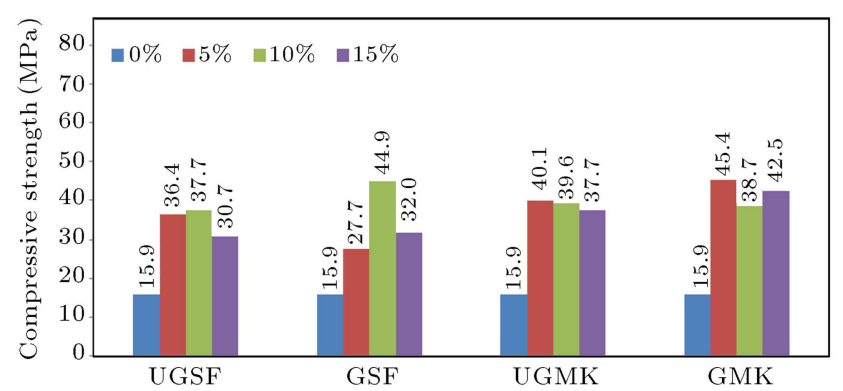

Figure 4(b). Compressive strength after curing in $\mathrm{H}_{2} \mathrm{SO}_{4}$.

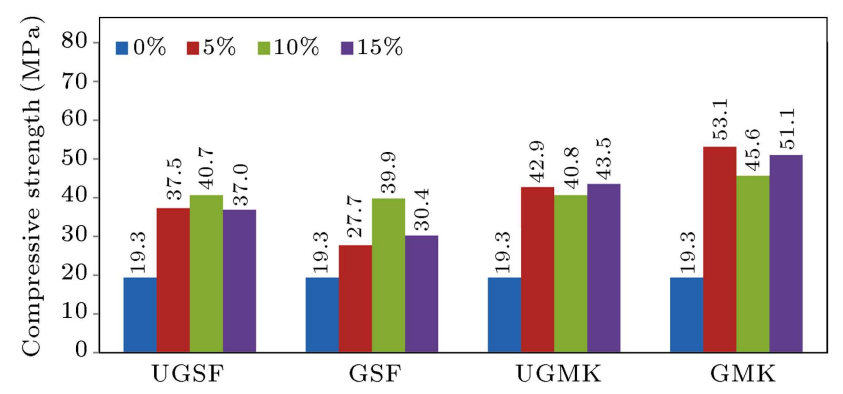

Figure 4(c). Compressive strength after curing in $\mathrm{NaCl}$.

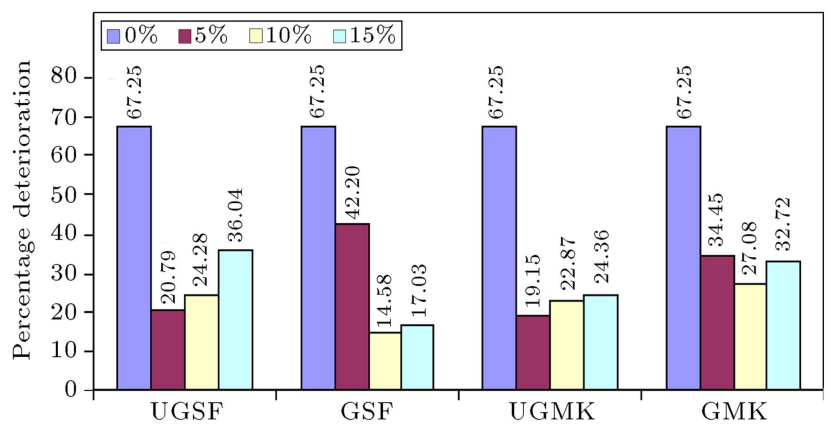

Figure 5(a). Percentage of deterioration in $\mathrm{H}_{2} \mathrm{SO}_{4}$.

concrete with partially replaced cementitious materials are showing better resistance to deterioration than control concrete. Figure 4(b) shows the comparative strength results, all mixes cured in $\mathrm{H}_{2} \mathrm{SO}_{4}$. Generally, it is observed that ultra-fine silica fume when used as supplementary cementitious materials are showing better resistance to deterioration than metakaolin in finely ground state. The rate of deterioration for cubes exposed to $\mathrm{H}_{2} \mathrm{SO}_{4}$ is shown in Figure 5(a).

\subsubsection{Rate of deterioration after curing in $\mathrm{NaCl}_{2}$}

A higher deterioration rate of $60.34 \%$ was observed for control concrete specimens when cured in $\mathrm{NaCl}_{2}$. On observing strength results of specimens cured in $\mathrm{NaCl}_{2}$ solution, the deterioration rates are once again more for control concrete specimens than for that of other mixes. A minimum deterioration rate of $12.71 \%$ was observed for UGMK15 and a higher rate of deterioration of $42.1 \%$ occurred for GSF5; the very fine nature of the GSF and being added in very small quantity might result in dissolving of the finer particles leading to greater deterioration effects. UGMK5 and GMK10 showed less deterioration rates of $13.45 \%$ and $14 \%$, respectively. Generally, the percentage of deterioration is low compared to the effect from acid curing due to the fact that $\mathrm{CaO}$ in cement does not usually react to sodium chloride which is a salt of an alkali metal; the reaction between $\mathrm{CaO}$ and $\mathrm{NaCl}$ is very slow, and hence the leached lime values are low. Since the leached lime value is very low, the deterioration percentage is also low. Figures 4(c) and 5(b) illustrate these details clearly.

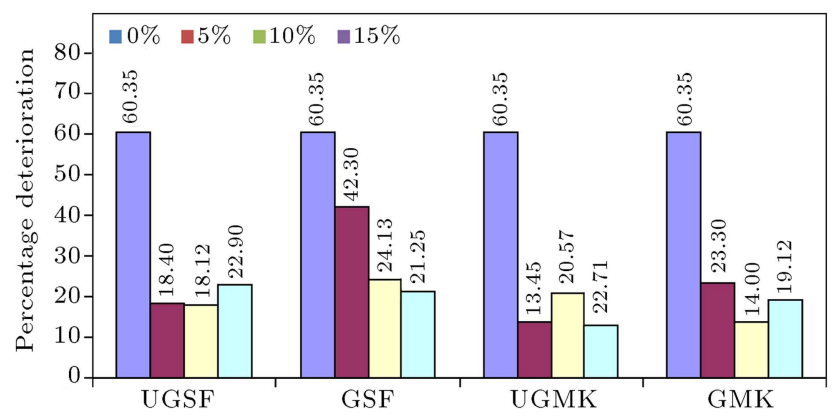

Figure 5(b). Percentage of deterioration in $\mathrm{NaCl}$. 


\subsection{Corrosion behavior of steel in concrete} 3.3.1. Significance of UGSF and UGMK

RCC cylindrical specimens exposed to $1 \%$ $\mathbf{H}_{2} \mathrm{SO}_{4}$. The corrosion of steel exposed to acid environment is found to be in the range of $-360 \mathrm{mV}$ to $-680 \mathrm{mV}$ which is very much higher than that of the specimens cast with supplementary cementitious materials. The corrosion range is observed as -190 to $-630 \mathrm{mV}$ for specimens with UGSF and is found to be in the range between $-110 \mathrm{mV}$ and $-250 \mathrm{mV}$ for specimens with GMK indicating the active state of steel. Figure 6(a) clearly shows the variation in the values. The value obtained is less due to the initial formation of calcium sulphate which plugs the pores of concrete, thereby preventing corrosive ions. Also, the duration of curing period is less and corrosion is the process which takes a long time to show its effect. Specimens with UGSF showed higher corrosion rate of $-680 \mathrm{mV}$; specimens with UGMK showed less corrosion of $-250 \mathrm{mV}$, indicating that mineral admixtures help in delaying corrosion process by blocking finer pores in concrete.

RCC cylindrical specimens exposed to $3 \%$ $\mathrm{NaCl}$. The same trend is maintained for cubes cured in base medium. Also, control specimens showed high corrosion rates, but slight variation was observed in results of specimens with UGSF in $5 \%, 10 \%$, and $15 \%$. Specimens cast with $15 \%$ UGSF showed a better corrosion resisting ability. The results are shown in Figure 6(b). The open circuit potential behavior of steel in concrete exposed to $3 \% \mathrm{NaCl}$ is found to vary initially in the range of $-190 \mathrm{mV}$ to $-520 \mathrm{mV}$; for specimens with UGMK, it is found to be in the range $-60 \mathrm{mV}$ to $-230 \mathrm{mV}$ indicating that metakaolin plays an effective role in delaying corrosion.

\subsubsection{Significance of UGSF and UGMK}

RCC cylindrical specimens exposed to $1 \%$ $\mathbf{H}_{2} \mathrm{SO}_{4}$. By referring to Figure 6(a), a great variation in results can be seen when the corrosion test results of control specimens and those with

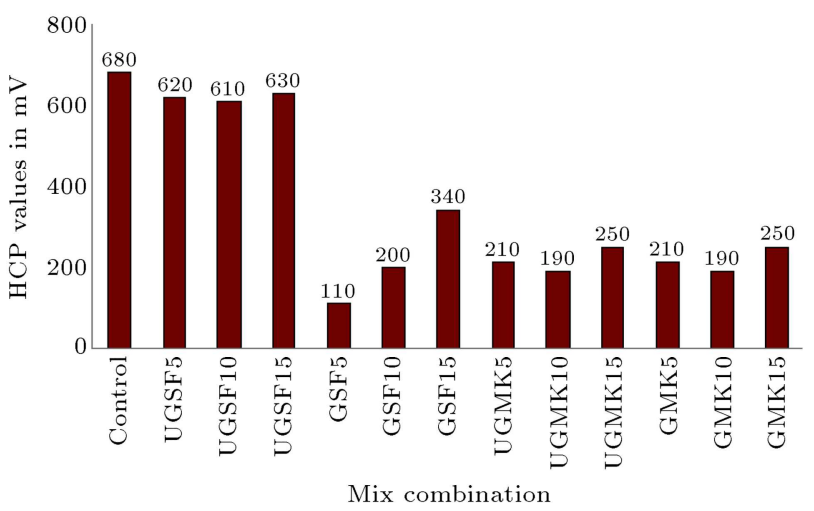

Figure 6(a). Corrosion rate of steel bar in $\mathrm{H}_{2} \mathrm{SO}_{4}$.

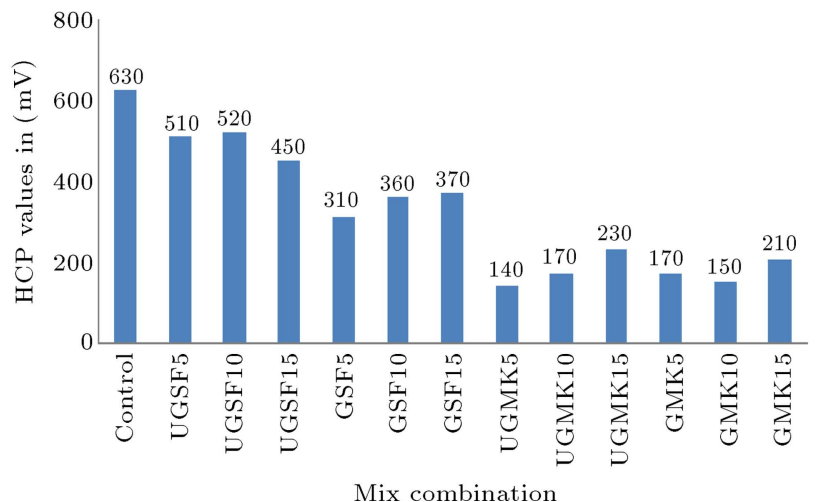

Figure 6(b). Corrosion rate of steel bar in $\mathrm{NaCl}$.

GSF and GMK are compared. Cubes with 5\% GSF showed a better corrosion resisting capability, and this decreased when the percentage of replacement was increased to $10 \%$ and $15 \%$; this may be due to the reason that the finer particles might have dissolved in the acid medium and may not be able to provide protection. Considering specimens with GMK, better resistance to corrosion is offered by UGMK10. Also, it can be noted that the difference in corrosion rates between control concrete specimens and those with partially replaced UGSF is very less. And, all showed higher rate of corrosion, whereas specimens cast with GSF showed good resistance.

RCC cylindrical specimens exposed to $3 \%$ $\mathrm{NaCl}$. GSF and GMK specimens cured in $3 \% \mathrm{NaCl}$ showed better corrosion resistance than control specimens, and the results are shown in Figure 6(b). Here, it can be seen that better corrosion resistance is given by GMK10 specimens. The corrosion resisting characteristics were almost the same for all levels of replacements in both GSF and GMK specimens and only a little variation was observed.

\subsection{Statistical analysis}

Standard deviation and coefficient of variation were calculated for performing the statistical analysis. Standard deviation measures the variation in the data. The ratio between standard deviation and mean of the data results in the coefficient of variation, which can be used for fixing the standard of the mixes prepared as mentioned by ACI 214 R-02 [28]. Table 5 shows the reference values for standards of the mixes having compressive strength greater than $34.5 \mathrm{MPa}$, taken from ACI 214 R-02. As per the guidelines, the mixes can be classified as excellent, very good, good, fair, and poor standards. On performing the statistical details and checking the 48 combinations of mixes, 4 replacement percentages $(0,5,10,15) \times 4$ admixtures (UGSF, GSF, UGMK, GMK) $\times 3$ curing conditions (water, $\mathrm{H}_{2} \mathrm{SO}_{4}, \mathrm{NaCl}$ ), it was observed that 23 mixes fell under excellent category, 15 mixes under very good 
Table 5. Standards of concrete control ACI 214 R-02 [28].

\begin{tabular}{ccccccc}
\hline \multirow{2}{*}{ Class of operation } & \multicolumn{5}{c}{ Overall variation* } \\
\cline { 2 - 6 } & Coefficient of variation for different control standard (\%) \\
\hline Laboratory trial batches & Below 3.5 & 3.5 to 4.5 & 4.5 to 5.5 & 5.5 to 7 & Above 7 \\
\hline
\end{tabular}

*For compressive strength greater than $34.5 \mathrm{MPa}$.

category, 6 mixes under good category, and 4 mixes under fair category. So, it is understood that the mixes were made with good quality control.

\section{Conclusion}

The following are the conclusions derived from the experiments conducted to study the effect of silica fume and metakaolin when used in unground (UGSF, UGMK) and ultra-fine (GSF, GMK) states as partial substitutes to cement in an aggressive environment.

1. It is evident from SEM results that effect of grinding did not affect the micro-structure of silica fume and metakaolin powders both in their unground and ultra-fine or ground states;

2. In general, the specimens with metakaolin as substitute cementitious material behaved better in both normal and aggressive environments than those with silica fume;

3. The compressive strength results of the specimens cured in different curing media showed that GMK has a better compressive strength and better deterioration resisting behavior than UGSF, GSF, or UGMK;

4. GMK5 showed higher compressive strength after 28- day curing in water and also after being exposed to $\mathrm{H}_{2} \mathrm{SO}_{4}$ acid environment;

5. GMK15 showed higher resistance compression after being exposed to $\mathrm{NaCl}$ marine environment;

6. Resistance of concrete with silica fume and metakaolin in unground and ground states exhibited better resistance against deterioration in plain cement concrete and rate of corrosion in reinforced cement concrete for all the combinations used. Resistance of admixed concrete against deterioration was found to be 2 to 4 times better than the control concrete;

7. In the case of concrete with silica fume, higher resistance against deterioration was observed in plain cement concrete with 5 and $10 \%$ in unground state (UGSF) and 10 and $15 \%$ in ultra-fine or ground state (GSF). In RCC, concrete with $5 \%$ silica fume was found to have higher resistance against corrosion, irrespective of unground (UGSF) and ground states (GSF);

8. Considering concrete with metakaolin, higher re- sistance against deterioration and corrosion was observed for concrete almost with 5 and $10 \%$ replacement in unground and ground states.

9. Based on the statistical results, it is inferred that the mixes were prepared with good quality control.

\section{Nomenclature}

SEM

$\mathrm{XRD}$

Scanning Electron Microscope

$\mathrm{XRF}$

X-ray Diffraction

$\mathrm{HCP}$

X-Ray Fluorescent

$\mathrm{UGSF} / \mathrm{MK}$

Half-Cell Potential

UGSF5/MK5 5\% Unground Silica Fume/Metakaolin

UGSF10/MK10 10\% Unground Silica Fume/Metakaolin

UGSF15/MK15 15\% Unground Silica Fume/Metakaolin

GSF/MK Ultra-Fine Ground Silica Fume/Metakaolin

GSF5/MK5 $5 \%$ Ultra-Fine Ground Silica Fume/Metakaolin

GSF10/MK10 10\% Ultra-Fine Ground Silica Fume/Metakaolin

GSF15/MK15 15\% Ultra-Fine Ground Silica Fume/Metakaolin

SCE Saturated Calomel Electrode

\section{References}

1. Pradhan, B. "Corrosion behavior of steel reinforcement in concrete exposed to composite chloride-sulfate environment", Construction and Building Materials, 22, pp. 398-410 (2014).

2. Resi Bazant, Z.P. "Physical model for steel corrosion in concrete sea structure-Theory", Journal of the Structural Division, 105(6), pp. 1137-1153 (1979).

3. Lu, C., Jin, W. and Lui, R. "Reinforcement corrosioninduced cover cracking and its time prediction for RC structures", Corrosion Science, 53(4), pp. 1337-1347 (2011).

4. Duffo, G.S., Morris, W., Raspini, I. and Saragori, C. "A study of steel rebars embedded in concrete during 65 years", Corrosion Science, 46, pp. 2143-2157 (2004).

5. Broomfield, J.P., Corrosion of Steel in Concrete: Understanding, Investigation and Repair, Second Edition, Taylor \& Francis Ltd. U.K. (2006). 
6. Bhaskar, S., Ravindra Gettu, Bharathkumar, B.H. "Corrosion of rebars in reinforced concrete - a review of the corrosion mechanisms, assessment techniques and control measures", ICI Journal, 12(3), pp. 35-54 (2011).

7. Silverman, D.C. and Carrico, J.E. "Electrochemical impedance technique -A practical tool for corrosion prediction", Corrosion, 44(5), pp. 280-287 (1998).

8. Gu, P. and Beaudoin, J.J. "Estimation of steel corrosion rate in reinforced concrete by means of equivalent circuit fittings of impedance spectra", Advances in Cement Research, 10(2), pp. 43-56 (1998).

9. Karthikeyan, J. and Shaheer Ali, K. "Comparative studies on mechanical properties in high performance concrete", Indian Concrete Journal, 88(9), pp. 35-45 (2014).

10. Hassan, K.E., Cabrera, J.G. and Maliehe, R.S. "The effect of mineral admixtures on the properties of high-performance concrete", Cement and Concrete Composites, 22(4), pp. 267-271 (2000).

11. McCarthy, M.J. and Dhir, R.K. "Development of high volume fly ash cements for use in concrete construction", Fuel, 84, pp. 1423-1432 (2005).

12. Lam, L., Wong, Y.L. and Poon, C.S. "Effect of fly ash and silica fume on compressive and fracture behaviors of concrete", Cement and Concrete Research, 28(2), pp. 271-283 (1998).

13. Shi, H., Xu, B. and Zhou, X.C. "Influence of mineral admixtures on compressive strength, gas permeability and carbonation of high performance concrete", Construction and Building Materials, 23, pp. 1980-1985 (2009).

14. Leea, C.Y., Leeb, H.K. and Leeb, K.M. "Strength and microstructural characteristics of chemically activated fly ash-cement systems", Cement and Concrete Research, 33, pp. 425-431 (2003).

15. Nazari, A. and Riahi, Sh. "The effects of $\mathrm{TiO}_{2}$ nano particles on physical, thermal and mechanical properties of concrete using ground granulated blast furnace slag as binder", Materials Science and Engineering A, 528, pp. 2085-2092 (2011).

16. Qing, Y., Zenan, Z., Deyu, K. and Shen, C.R. "Influence of nano- $\mathrm{SiO}_{2}$ addition on properties of hardened cement paste as compared with silica fume", Construction Building Materials, 21(3), pp. 539-545 (2007).

17. Jo, B.W., Kim, C.H. and Tae, G.H. "Characteristics of cement mortar with nano- $\mathrm{SiO}_{2}$ particles", Construction Building Materials, 21(6), pp. 1351-1355 (2007).

18. Morsy, M.S., Alsayed, S.H. and Aqel, M. "Effect of nano-clay on mechanical properties and microstructure of ordinary portland cement mortar", International Journal of Civil \& Environmental Engineering IJCEE-IJENS, 10(1), pp. 23-27 (2008).

19. Kartikeyan, B., Sumanth, K., Harsharvardhan, G., Rajasekharareddy, A. and Dhinakaran, G. "Microstructure analysis and strength properties of concrete with nano $\mathrm{SiO}_{2}$ ", International Journal of Chem Tech Research, 6(5), pp. 3004-3013 (2014).
20. Karthikeyan, B. and Dhinakaran, G. "Effect of grinding on strength and durability of GGBFS based concrete", Jordan Journal of Civil Engineering, 8(4), pp. $442-454$ (2014).

21. Karthikeyan, B. and Dhinakaran, G. "Effect of grinding on physico-mechanical properties of ultrafine micro-silica", Asian Journal of Applied Sciences, 7(4), pp. 182-193 (2014).

22. Geneyisi, E., Gesoglu, M. and Mermerdas, K. "Strength deterioration of plain and metakaolin concretes in aggressive sulfate environments", Journal of Materials in Civil Engineering, 22(4), pp. 403-407 (2010).

23. Topcu, I.B. and Boga, A.R. "Effect of ground granulate blast-furnace slag on corrosion performance of steel embedded in concrete", Materials and Design, 31, pp. 3358-3365 (2010).

24. ACI 211, Standard Practice for Selecting Proportions for Normal, Heavyweight and Mass Concrete, American Concrete Institute, Farmington Hills, MI, USA (1991).

25. BS 1881-108 Testing Concrete - Method for Making Test Cubes from Fresh Concrete, British Standards Institution, 2 Park Street London W1 A 2BS (1983).

26. ASTM C 876-91, Standard Test Method for HalfCell Potentials of Uncoated Reinforcing Steel in Concrete, ASTM International, West Conshohocken, Pennsylvania (1991).

27. Peter, V.N., Mette, R.G. and Bernhard, E. "Corrosion rate of steel in concrete: evaluation of confinement techniques for on-site corrosion rate measurements", Materials and Structures, 42, pp. 1059-1076 (2009).

28. American Concrete Institute, Evaluation of Strength Test Results of Concrete, ACI 214 R-02, pp. 214R-(1-20) (2002).

\section{Biographies}

Balasubramanian Karthikeyan is a $\mathrm{PhD}$ candidate in SASTRA University in the School of Civil Engineering. He received his BE degree in Civil Engineering from Bharathidasan University and ME degree in Structural Engineering from Anna University in 2002 and 2005, respectively. His research interests include strength and durability characteristics of concrete made with ultra-fine mineral admixture.

Govindasamy Dhinakaran is a Professor in SASTRA University in the School of Civil Engineering. He received his BE degree in Civil Engineering from Bharathidasan University, ME degree from National Institute of Technology, and $\mathrm{PhD}$ degree from Indian Institute of Technology Madras in Offshore Structures in 1988, 1990, and 2003, respectively. His research interests include sustainable materials and materials in an aggressive environment. 